\title{
Does inter-plant variation in sprouting time affect the growth/reproduction trade-off and herbivory in a tropical tree species?
}

\author{
Marcilio Fagundes ${ }^{\star *}$, Renata C. Xavier', Letícia F.L. Ramos', Walisson K. Siqueira', Ronaldo Reis-Junior ${ }^{2}$ \\ and Matheus L. Souza ${ }^{1,3}$
}

Received: July 1, 2016

Accepted: October 11, 2016

\begin{abstract}
The timing of phenological events varies within and among populations, affecting the performance of individual plants differently. We evaluated the effects of relative variation in sprouting time on the display of reproductive events, vegetative growth and herbivory in Copaifera langsdorffii (Fabaceae). A total of 93 trees of C. langsdorffii was monitored daily to determine their sprouting time. We collected ten terminal branches of each plant to evaluate vegetative growth, production of defense compounds and insect herbivore damage. The sprouting time for the studied population lasted 67 days. Variation in sprouting time did not affect the probability of plants to enter the reproductive stage. Plants that entered the reproductive stage showed greater vegetative biomass. Variation in sprouting time had a negative relationship with branch growth and a positive relationship with the number of leaflets. Leaf phenol concentration did not vary in relation to sprouting time or plant phenology, but herbivory was higher in plants that sprouted later. The relationships among plant sprouting time, vegetative development and display of reproductive stage in $C$. langsdorffii are discussed. The results of this study also suggest that early sprouting prior to the rainy season is a strategy used by $C$. langsdorffii to escape herbivores attacks.
\end{abstract}

Keywords: Copaifera langsdorffii, flowering trigger, herbivory escape, phenological asynchrony, resource allocation

\section{Introduction}

Phenology describes the timing and factors that regulate transitions between stages in the life cycle of an organism (Fagundes 2014). Synchronism of phenological events in plant species (e.g., sprouting, flowering, and fruiting) can vary among and within populations (Singh \& Kushwaha 2005). Ecological causes of variation in phenology include differences in temperature, photoperiod, moisture, and soil quality (Campo et al. 2010; Yang \& Rudolf 2010).
Furthermore, inter-plant variation in phenological events can be caused by genetic differences in age, size, and reproductive effort in the previous years, as well as interactions with higher trophic levels (Schemske et al. 1978; Souza \& Fagundes 2016).

During a phenological cycle, plants must acquire resources to invest in growth, reproduction and the production of compounds for defence against herbivores (Herms \& Mattson 1992; Stamp 2003; Costa et al. 2016). Usually the resource demand for these three processes

\footnotetext{
${ }^{1}$ Laboratório de Biologia da Conservação, Universidade Estadual de Montes Claros, 39.401-089, Montes Claros, MG, Brazil

${ }^{2}$ Laboratório de Ecologia Computacional e Comportamental, Universidade Estadual de Montes Claros, 39.401-089, Montes Claros, MG, Brazil

${ }^{3}$ Laboratório de Fisiologia Vegetal, Universidade Federal de Minas Gerais, 31.270-901, Belo Horizonte, MG, Brazil

* Corresponding author: marcilio.fagundes@gmail.com
} 
cannot be met simultaneously, thereby generating a tradeoff in resource allocation among the different nutrient drains of the plant (Obeso 2002; Weiner et al. 2009). Trade-offs between reproduction and growth is a common phenomenon in higher plants. For example, during fruit development, plants may reduce or even stop growing because fruits are strong nutrient drains (Larcher 1995). In addition, scarcity of resources can trigger the reproductive phenophase in perennial plants (Yang \& Rudolf 2010). Plants subjected to long periods of strictly vegetative growth prior to initiating reproductive activity have greater resource acquisition and resource stores (Araújo et al. 1998; Nord et al. 2011). Therefore, intra-population variation in plant phenology, in particular sprouting time, can affect vegetative and reproductive development of plants (Dahlgren 2007; Parachnowitsch et al. 2012).

From a co-evolutionary perspective, variation in sprouting time within a plant population can play a relevant role in the plant-herbivore interactions (Forister 2005; Fagundes 2014). Plants try to reduce herbivore actions directly by using the host satiation mechanism or producing resource patches that vary over time (Schaik et al. 1993; Fei et al. 2014; Souza \& Fagundes 2016). In contrast, herbivores try to synchronize their life cycle with the appearance of target-organs in the plant to ensure greater offspring performance (Yukawa \& Akimoto 2006; Thompson \& Gilbert 2014). Indirectly, variation in sprouting time produce resource patches that change in quantity and quality for herbivores. For example, early-sprouting plants can accumulate more resources during an extended vegetative stage, resulting in greater vegetative growth and a greater amount of secondary compounds (Forister 2005; Costa et al. 2016). Thus, phenological asynchronies within a plant population can generate patches of resources that vary in quality (e.g., concentrations of primary and secondary metabolites and morphological traits) and quantity over time (Forister 2005; Parachnowitsch et al. 2012; Fagundes 2014).

Copaifera langsdorffii (Fabaceae) is a tropical tree species that reaches up to $20 \mathrm{~m}$ in height in the Brazilian Cerrado. This species exhibits supra-annual fruiting (i.e., there are years of intense fruit set followed by years of low or no fruit production), complete deciduousness in the dry season (mainly from July to September) with leaf emission occurring immediately after the fall of the old leaves produced in the previous year (Souza \& Fagundes 2016). Moreover, plants of C. langsdorffii exhibit wide intrapopulation variation in leaf sprouting time in Cerrado areas (Fagundes 2014). Flowering occurs from November to December and fruits ripen from August to September of the following year (Fagundes et al. 2013). C. langsdorffii experiences a high diversity of free-feeding herbivorous insects, but the mechanism that regulates this diversity is still poorly known (see Silva et al. 2009; Costa et al. 2016). We formulated the hypothesis that early-sprouting plants of $C$. langsdorffii accumulate more resources due their extended vegetative stage. Thus, this study tested the following predictions of this hypothesis: (i) early-sprouting plants would have a greater probability of displaying the reproductive stage, (ii) early-sprouting plants would have greater vegetative growth and (iii) early-sprouting plants would produce greater amounts of secondary compounds and would be subjected to lower levels of herbivory.

\section{Materials and methods}

\section{Study area}

The study was performed in a private reserve of approximately 25 hectares located in the city of Montes Claros (16 $40^{\prime} 26^{\prime \prime}$ 'S and 43⒋ $44^{\prime \prime} \mathrm{W}$ ) in northern Minas Gerais, Brazil. This region is located between the Cerrado and Caatinga domains and has a semi-arid climate characterized by well-defined dry and rainy seasons (Fagundes et al. 2013). The average annual temperature is approximately $23^{\circ} \mathrm{C}$, and the average precipitation is about $1,000 \mathrm{~mm} /$ year, with the rainy season being concentrated between November and February (Costa et al. 2016). The soil of the study area is dystrophic with a well-developed herbaceous subshrub layer (Fagundes et al. 2011; Souza \& Fagundes 2016).

\section{Field work}

A total of 93 adult plants of Copaifera langsdorffii Desf. were marked in the study area during May 2012. Individuals were between 8 and $12 \mathrm{~m}$ tall and appeared in good physiological condition (i.e., abundant crown with the absence of lianas and parasites). Copaifera langsdorffii was irregularly distributed in the study area with the distance among trees varying from 7 to $45 \mathrm{~m}$. All individuals were monitored daily from July 2012 to May 2013 in order to determine the precise date of sprouting for each individual plant and determine the relative variations in sprouting time (days) among all plants of the population. Because many plants did not enter a reproductive stage, we grouped the plants into two phenological groups: (1) plants that performed the reproductive stage and (2) plants that did not performed the reproductive stage.

During June 2013 (prior to leaf fall), we collected ten terminal branches (approximately $30 \mathrm{~cm}$ long) from each individual plant to assess the effect of relative variation in sprouting time on vegetative growth and leaf herbivory. Because $C$. langsdorffii is deciduous, we were able to identify branches that growth during previous growth station (July 2012 to June 2013) and so, it was possible to access the biomass invested by each plant. Branches were collected from different parts of the crown in order to obtain samples from the entire individual and avoid bias caused by the effect of microhabitat on branch development and herbivory (Costa et al. 2010). 


\section{Laboratory assay}

The ten branches collected from each individual were taken to Conservation Biology Laboratory of the Unimontes (State University of Montes Claros) to quantify vegetative investment (branch growth, average number of leaflets per branch, leaf biomass and total biomass of branches), phenol concentration in leaf tissues and herbivory of each plant. Branch growth was assessed for each plant by determining the average length of internodes of the principal branch. Moreover, all leaflets and shoots present in those branches were used to determine leaflet number, leaflet biomass and shoot biomass. All leaflets and shoots present on the ten branches per tree were dried in an oven at $70^{\circ} \mathrm{C}$ for $72 \mathrm{~h}$, and weighed on a precision electronic scale $(0.01 \mathrm{mg} /$ Shimadzu Corp. AUW 220) to determine dry leaf and shoot biomass.

Total phenolic content was determined by spectrophotometry using the Folin-Ciocalteau methodology (Swain \& Hillis 1959) with gallic acid serving as a standard. Initially, leaf extract was prepared for each individual used in the study by diluting $0.5 \mathrm{~g}$ pounded leaves in one $\mathrm{mL}$ of methanol. The $0.5 \mathrm{~g}$ of leaves was obtained from 50 mature leaves collected randomly from tree crowns. Next, $500 \mu \mathrm{L}$ of the extract was transferred to tubes containing $250 \mu \mathrm{L}$ Folin-Ciocalteu's reagent. After waiting for 10 minutes, 500 $\mu \mathrm{L}$ of a sodium carbonate solution $(10 \% \mathrm{w} / \mathrm{v})$ was added to the sample. The tubes were then allowed to stand at room temperature for $30 \mathrm{~min}$ before absorbance was measured at $743 \mathrm{~nm}$. The concentration of polyphenols in the samples was derived from a standard curve of gallic acid ranging from $20,30,40,60$, and $80 \mu \mathrm{g} / \mathrm{mL}$. Total phenolic content was expressed as gallic acid equivalents (GAE) in $\mathrm{mg} / \mathrm{g}$ of dry leaf extract.

We randomly selected 30 leaves per individual (three leaves per sampled branch) to determinate the percentage of leaf area lost due to damage from chewing by herbivores. These leaves were digitalized and their total and removed areas were estimated using the software ImageJ (Rasband 1997-2014).

\section{Statistical analysis}

The effect of variation in plant sprouting time and phenological group (reproductive or non-reproductive plants) on vegetative growth and phenolic compounds were tested using generalized linear models (GLMs) followed by ANOVA. In this case, plant sprouting time and phenological group were used as explanatory variables and branch growth, average number of leaflets per branch, leaf biomass, total biomass of branches or phenol concentration in leaf tissues were considered response variables. Since the response variables are continuous, we tested the models using F-test based on the Gaussian distribution prior to submitting the models to analysis of residues to test their adequacy at meeting statistical assumptions (Crawley 2007).
The effects of plant sprouting time, phenological group, vegetative growth and phenol concentration in leaf tissues on percentage of leaf herbivory were tested with GLMs followed by ANOVA. Thus, herbivory was the response variable and variation in sprouting time, phenological groups, branch growth, average number of leaflets, leaf biomass and phenol concentration were used as explanatory variables. The Akaike Information Criteria for small samples (AICc) was used for ordered explanatory variables and to select most parsimonious model. These procedures were carried out using the MuMIn package of R software.

\section{Results}

Sprouting of Copaifera langsdorffii started on July 27 $7^{\text {th }}$, 2012 and continued until October $1^{\text {st }}, 2012$ (Fig. 1A). Therefore, the sprouting time for the 93 individuals lasted a total of 67 days. Only 38 individuals (40.9\%) entered the reproductive stage. Variation in sprouting time did not differed between plants that reproduced and those plants that $\operatorname{did} \operatorname{not}(\mathrm{F}=0.3455, \mathrm{P}=0.5581$, Fig. 1B).

Variation in sprouting time and the onset of reproductive events affected branch growth (Tab. 1). In fact, sprouting time had a negative relationship with branch growth while individuals that went into the reproductive stage had greater branch growth than non-reproductive individuals (Fig. 2A). Leaf biomass was negatively related with variation in sprouting time (Fig. 2B) while total biomass was greater in plants that entered the reproductive stage (Fig. 2C). Sprouting time was positively related to the number of leaflets per branch (Fig. 2D). Sprouting time and plant phenological group did not affect leaf phenol concentration $(\mathrm{F}=0.0159, \mathrm{P}=0.9000)$.

Among all explanatory variables tested, only sprouting time affected herbivory on C. langsdorffii leaves (Tab. 1). In fact, there was a positive relationship between percentage of foliar herbivory and variation in sprouting time (Fig. 3 ), suggesting that early-sprouting plants had lower rates of herbivory.

\section{Discussion}

The results of this study showed that trees of Copaifera langsdorffii are deciduous and exhibit wide variation in leaf sprouting time. However, previous studies conducted in semideciduous forest suggest that $C$. langsdorffii is semideciduous, and leaf production by individuals is highly synchronized (Pedroni et al. 2002 and references). Climate, especially water availability, can influence the intensity and duration of vegetative phenophases of plant populations (Silveira et al. 2013). Thus, it is probable that plants of $C$. langsdorffii adjust their phenological behavior according to environmental conditions and this phenotypic plasticity 

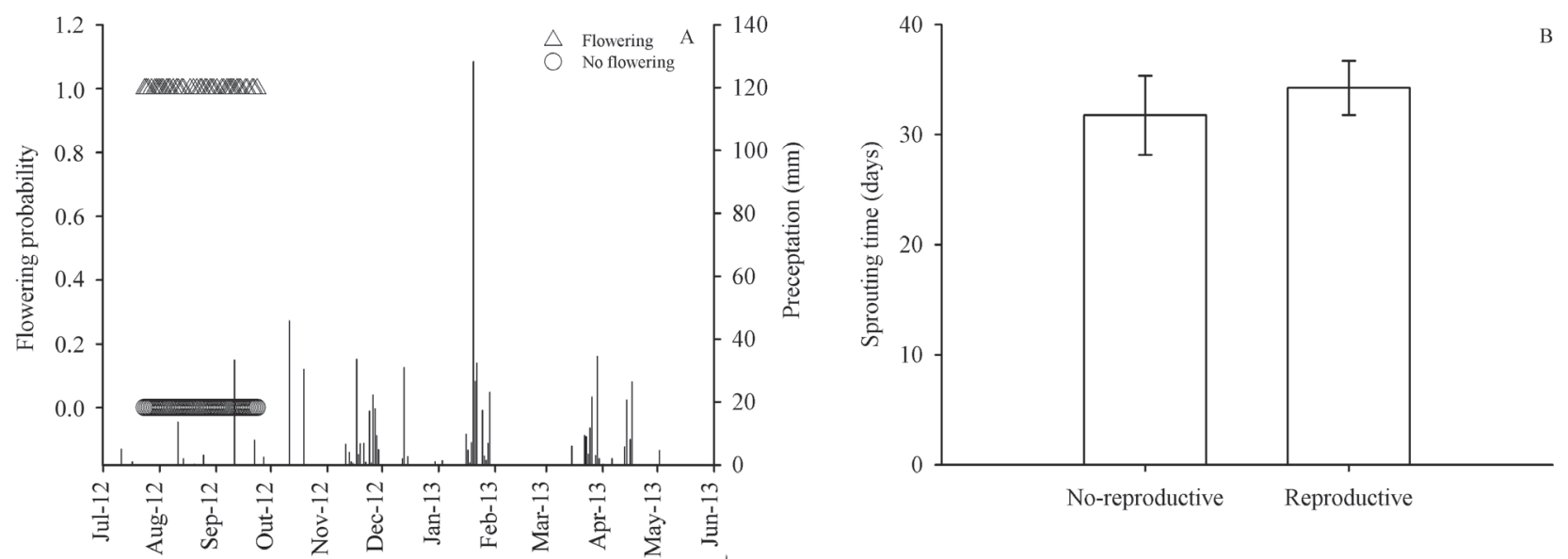

Figure 1. Variation in sprouting time of Copaifera langsdorffii trees: (a) specific date of sprouting for reproductive ( $\mathrm{n}=38$ ) and nonreproductive $(n=55)$ plants (right axis shows the daily precipitation during 12 moths, indicating that plant sprouting occurs prior to the rainy season); and (b) variation in sprouting time (mean $\pm \mathrm{SE}$ ) between reproductive and on-reproductive plants.

Table 1. Summary of minimal adequate models showing the effects of variation in sprouting time and phenological group on vegetative traits (branch growth, leaf biomass, total biomass and leaflets per branch) and the effects of variation in sprouting time on leaf herbivory of Copaifera langsdorffii.

\begin{tabular}{|l|l|c|c|c|c|c|}
\hline Response variables & Explicative variables & Deviance & Df & Residual deviance & F-values & P-values \\
\hline Branch growth & Sprouting time & 2.333 & 64 & 40.711 & 3.894 & 0.052 \\
\hline & Phenological group & 2.964 & 63 & 37.748 & 4.946 & 0.029 \\
\hline Leaf biomass & Sprouting time & 37.232 & 64 & 367.78 & 6.684 & 0.012 \\
\hline Total biomass & Phenological group & 65.891 & 64 & 804.23 & 5.243 & 0.025 \\
\hline Leaflets per branch & Sprouting time & 10800 & 64 & 100207 & 6.897 & 0.010 \\
\hline Leaf herbivory & Sprouting time & 0.273 & 64 & 2.244 & 7.808 & 0.006 \\
\hline
\end{tabular}

could contribute to a broader niche breadth, thereby explaining the success of $C$. langsdorffii over a wide range of different habitats (see Souza \& Fagundes 2014).

The transition from a vegetative to a flowering stage in perennial plants is regulated by a complex combination of environmental and internal plant signals. Environmental cues include seasonal changes in photoperiod, vernalization, light intensity and spectral quality, and nutrient or water availability (Fenner 1998; Hanke et al. 2007). Furthermore, endogenous signals, such as repression and expression of genes associated with variation in hormone levels, influence flowering display (Huijser \& Schmid 2011). Generally, perennial plants must accumulate resources during their vegetative growth to invest in reproductive events, and the onset of flowering can be inhibited in the absence of an ideal quantity and quality of resources (Saulnier \& Reekie 1995; Canto et al. 2004).

Temporal variation in sprouting time can affect resource allocation because early-sprouting plants can accumulate more resources during an extended period of vegetative growth (Huijser \& Schmid 2011). Hence, we would expect early-sprouting trees of $C$. langsdorffii to have a higher probability of entering the reproductive phase. However, this hypothesis was refuted in our study because the variation in sprouting time did not differ among reproductive and non-reproductive plants. Moreover, as observed by Costa et al. (2016), flowering plants showed greater vegetative growth in comparison to no flowering plants. Because the study plants are located in a very homogenous environment, and the sprouting time did not differ between flowering and non-flowering plants, it is probable that resource acquisition and accumulation in previous years may be important in determining the probability that plants display reproductive events (Costa et al. 2016; Obeso 2002; Sandvik \& Eide 2009).

The results of this study also showed that earlier sprouting plants had greater branch growth while later sprouting plants had a higher number of leaflets per branch. In this case it is reasonable to think that branches that had greater internode size also had a smaller number of ramifications and, consequently, a lower number of leaflets. However, several authors (Baldwin et al. 1998; Mole 1994; Costa et al. 2016) have called attention to the interpretation of plant resource reallocation because the understanding of all the metabolic routes of plants is still limited. 

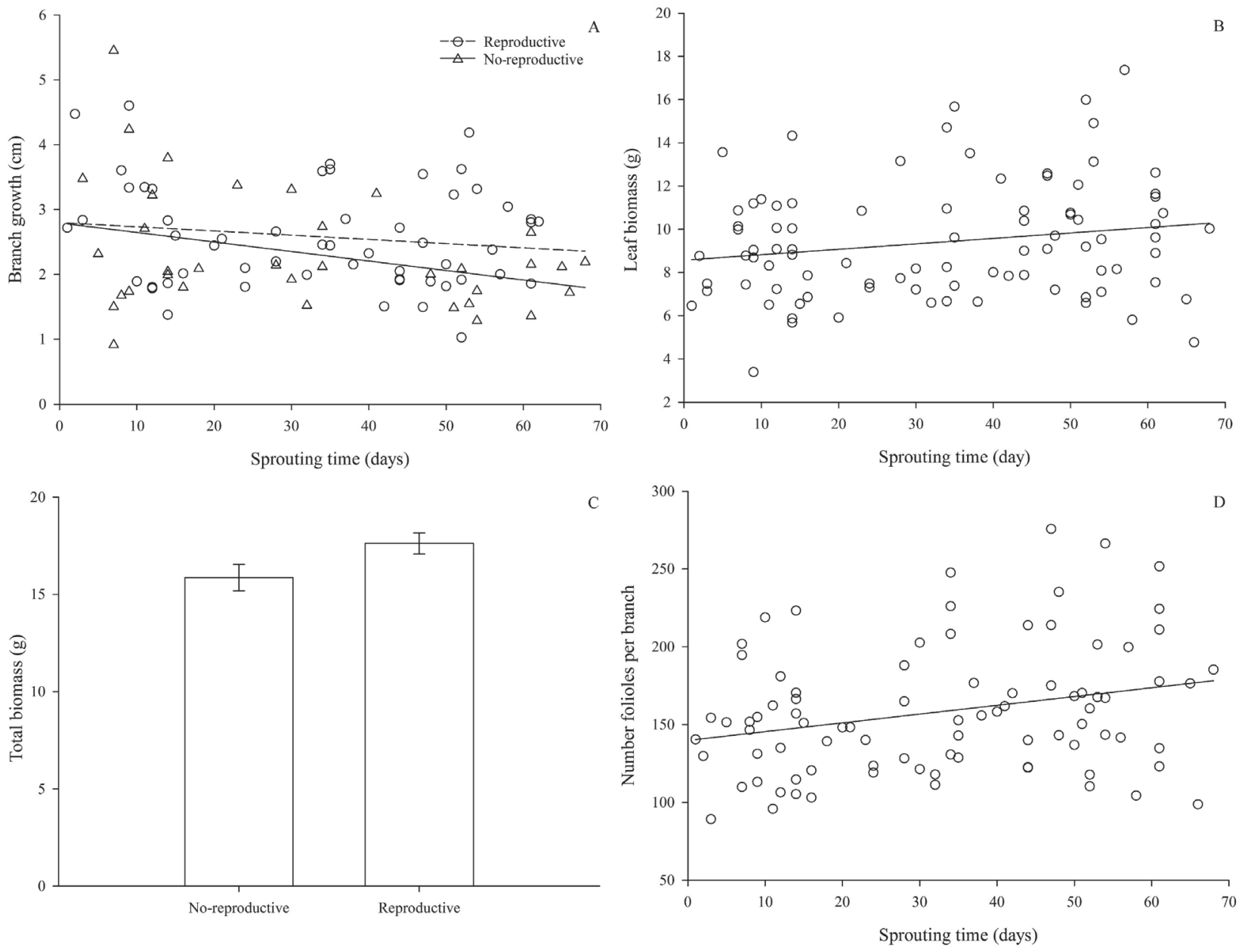

Figure 2. Effects of variation in sprouting time and phenological groups on (a) branch growth, (b) dry leaf biomass, (c) total dry biomass and (d) number of leaflets per branch of Copaifera langsdorffii trees.

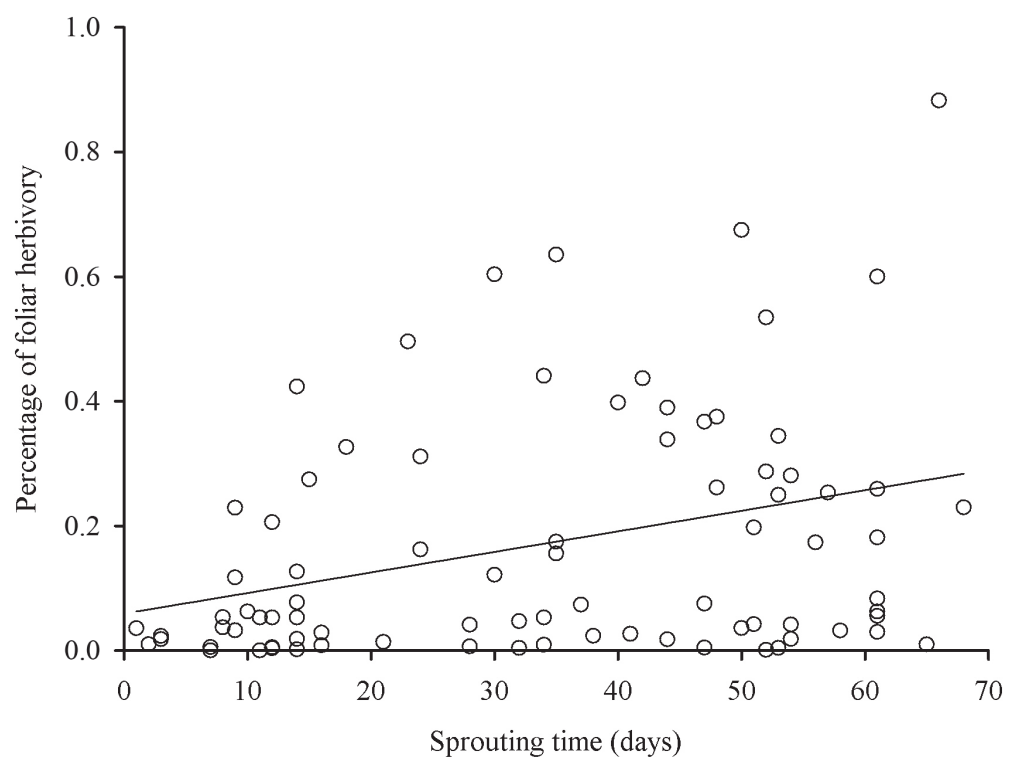

Figure 3. Relationship between relative variation in sprouting time and percentage of foliar herbivory in trees of Copaifera langsdorffii. 
Perhaps the most common result found in the literature concerning interactions between phytophagous insects and plant phenology is that herbivore attack is concentrated on new leaves (Forister 2005), because new leaves are richer in water and nitrogen while older leaves are sclerophilous and accumulate more allelochemicals (Coyle et al. 2010; Liu et al. 2010). Another common pattern concerning herbivoreplant interactions is that early-sprouting plants are more heavily attacked by herbivores than later-sprouting plants (Fenner 1998; Fox et al. 1997), because early-sprouting plants provide more resources for herbivore development for a longer period of time (Forister 2005; Yukawa \& Akimoto 2006). However, some studies also have related greater herbivory to later sprouting plants. For example, Sloan (2007) showed that herbivory by Pseudosphinx tetrio on Plumeria alba occurred predominantly during the wet season, when plant leaf production is in decline. This author also suggests that the strategy of sprouting before the wet season serves as a mechanism to avoid herbivores because insect herbivores are more abundant in the wet season.

The results of this study showed that later-sprouting plants had greater leaf herbivory, but no relation was observed between leaf phenol concentrations and herbivory or plant sprouting time. Therefore, our results did not support the prediction that early-sprouting plants would produce greater amounts of secondary compounds and would be subject to lower levels of herbivory. At this point two questions must be considered. First, while sclerophylly and phenolic compounds dose-dependent are strategies used by plants with long-lived leaves for avoid herbivores, deciduous plants can afford the replacement of damaged short-lived leaves (Neves et al. 2010). Thus, because trees of C. langsdorffii are highly caduceus annually, it would be unlikely that plants would invest in dose-dependent compounds to inhibit herbivore attack. Secondly, leaf production by trees of $C$. langsdorffii is concentrated to the period prior to the rainy season, whereas herbivorous insects reach their greatest abundance during the rainy season (Leal et al. 2015). Therefore, earlier sprouting seems to be a phenological strategy used by plants of $C$. langsdorffii to escape herbivorous insect attacks.

Finally, our study on C. langsdorffii showed that differences in sprouting time do not only affect vegetative development of plants, but may also alter interactions with other trophic levels. Here it is important to point out that our study took place in a single seasonal environment, and the study species has a wide geographic distribution, occurring across several habitats such as Atlantic Forest, Caatinga and Cerrado (Souza \& Fagundes 2016). Moreover, because plant phenology can be affected by habitat traits, understanding the interactions among environmental traits, plant phenology, and their effects on other trophic levels is particularly important for predicting how global climate change can affect the organization of natural communities (Parachnowitsch et al. 2012).

\section{Acknowledgements}

We thank all the collaborators of the Laboratório de Biologia da Conservação da UNIMONTES for logistical support in the field work. The authors thank the Cristina Bastias for text technical review. The study was carried out with financial support from Fundação de Amparo a Pesquisa do Estado de Minas Gerais (FAPEMIG APQ 01926.11) and Programa de Pós-Graduação Stricto Sensu em Ciências Biológicas (PPGCB) da UNIMONTES. The authors also acknowledge CAPES and FAPEMIG for research grants.

\section{References}

Araújo AP, Teixeira MG, Almeida DL. 1998. Variability of traits associated with phosphorus efficiency in wild and cultivated genotypes of common bean. Plant Soil 203: 173-182.

Baldwin IT, Gorham D, Schmelz EA, Lewandowski CA, Lynds, GY. 1998. Allocation of nitrogen to an inducible defense and seed production in Nicotiana attenuata. Oecologia 115: 541-552.

Campo I, Christopher MU, Calera A, Balbontín C, González-Piqueras J. 2010. Assessing satellite-based basal crop coefficients for irrigated grapes (Vitis vinifera L.). Agricultural and Water Management 98: 45-54.

Canto A, Parra-Tabla V, García-Franco JG. 2004. Variations in leaf production and floral display of Anthurium schechtendallii (Araceae) in response to herbivory and environment. Functional Ecology 18: 692-99.

Costa FV, Fagundes M, Neves FS. 2010. Arquitetura da planta e diversidade de galhas associadas à Copaifera langsdorffii (Fabaceae). Ecología Austral 20: 9-17.

Costa FV, Reis-Júnior R, Queiroz ACM, Maia MLB, Fagundes M. 2016. Resource allocation in Copaifera langsdorffii (Fabaceae): how supra annual fruiting affect plant characteristics and higher trophic level? Revista de Biología Tropical 64: 507-520.

Coyle DR, Jordan MS, Raffa KF. 2010. Host plant phenology affects performance of an invasive weevil, Phyllobius oblongus (Coleoptera: Curculionidae), in a Northern Hardwood Forest. Environmental Entomology 39: 1539-1544.

Crawley MJ. 2007. The R Book. New York, John Wiley and Sons.

Dahlgren JP, Zeipel HV, Ehrlén J. 2007. Variation in vegetative and flowering phenology in a forest herb caused by environmental heterogeneity. American Journal of Botany 94: 1570-1576.

Fagundes M. 2014. Galling insect community associated with Copaifera langsdorffii (Fabaceae): the role of inter- and intra-annual host plant phenology, In: Fernandes GW, Santos JC. (eds.) Neotropical Insect Galls. New York, Springer. p. 163-177.

Fagundes M, Camargos MG, Costa FV. 2011. A Qualidade do solo afeta a germinação das sementes e o desenvolvimento das plântulas de Dimorphandra mollis Benth. (Leguminosae: Mimosoidae). Acta Botanica Brasilica 25: 908-915.

Fagundes M, Maia MLB, Queiroz ACM, Fernandes GW, Costa F.V. 2013. Seed predation of Copaifera langsdorffii Desf. (Fabaceae: Caesalpinioideae) by Rhinochenus brevicollis Chevrolat (Coleoptera: Curculionidae) in a Cerrado Fragment. Ecología Austral 23: 218-221.

Fei M, Gols R, Harvey JA. 2014. Seasonal phenology of interactions involving short-lived annual plants, a multivoltine herbivore and its endoparasitoid wasp. Journal of Animal Ecology 83: 234-244.

Fenner M. 1998. The phenology of growth and reproduction in plants. Perspectives in Plant Ecology, Evolution and Systematics 1: 78-91.

Forister ML. 2005. Influence of host plant phenology on Mitoura nelson (Lepidoptera: Lycaenidae). Annals of the Entomological Society of American 98: 295-301. 


\section{Marcilio Fagundes, Renata C. Xavier, Letícia F.L. Ramos, Walisson K. Siqueira, Ronaldo Reis-Junior and Matheus L. Souza}

Fox CW, Thakar, MS, Mousseu TM. 1997. Egg size plasticity in a seed beetle: an adaptive maternal effect. The American Naturalist 149: 149-163.

Hanke MV, Flachowsky H, Peil A, Hättasch C. 2007. No flower no fruit genetic potentials to trigger flowering in fruit trees. Genes, Genomes and Genomics 1: 1-20.

Herms DA, Mattson WJ. 1992. The dilemma of the plants: to grow or to defend. Quarterly Review of Biology 67: 283-335.

Huijser P, Schmid M. 2011. The control of developmental phase transitions in plants. Development 138: 4117-4129.

Larcher W. 1995. Physiological plant ecology. Berlin, Springer.

Leal CRO, Fagundes M, Neves FS. 2015. Change in herbivore insect communities from adjacent habitats in a transitional region. Arthropod-Plant Interactions 9: 311-320.

Liu ZG, Cai YL, Li K. 2010. Induced responses in the subtropical evergreen, broad-leaf tree Schima superba: Effects of simulated herbivory on leaf quality and subsequent insect attack during leaf expansion. International Journal of Experimental Botany 79: 81-86

Mole S. 1994. Trade-offs and constraints in plant-herbivore defense theory - a life history perspective. Oikos 71: 3-12.

Neves FS, Araújo LS, Fagundes M, et al. 2010. Canopy herbivory and insect herbivore diversity in a dry forest-savanna transition in Brazil. Biotropica 42: 112-118.

Nord EA, Shea K, Lynch JP. 2011. Optimizing reproductive phenology in a two-resource world: a dynamic allocation model of plant growth predicts later reproduction in phosphorus-limited plants. Annals of Botany 108: 391-404.

Obeso JR. 2002. The costs of reproduction in plants. New Phytologist 155: 321-348.

Parachnowitsch AL, Caruso CM, Campbell S.A, Kessler A. 2012. Lobelia siphilitica plants that escape herbivory in time also have reduced latex production. PLoS ONE 7(5): e37745. doi:10.1371/journal. pone. 0037745

Pedroni F, Sanchez M, Santos FAM. 2002. Fenologia da copaíba (Copaifera langsdorffii Desf. Leguminosae, Caesalpinioideae) em uma floresta semidecídua no sudeste do Brasil. Revista Brasileira de Botânica 25: $183-194$

Rasband WS. 1997-2007. ImageJ. Bethesda, National Institutes of Health.

Sandvik SM, Eide W. 2009. Costs of reproduction in circumpolar Parnassia palustris in light of global warming. Plant Ecology 205: 1-11.
Saulnier TP, Reekie EG. 1995. Effect of reproduction on nitrogen allocation and carbon gain in Oenothera biennis. Journal of Ecology 83: 23-29.

Schaik CP, Terborgh JW, Wright SJ. 1993. The Phenology of Tropical Forests: Adaptive Significance and Consequences for Primary Consumers. Annual Review of Ecology and Systematics 24: 353-377.

Schemske DW, Willson MF, Melampy MN, et al. 1978. Flowering ecology of some spring woodland herbs. Ecology 59: 351-366.

Silva JO, Jesus FM, Fagundes M, Fernandes GW. 2009. Esclerofilia, taninos e Insetos herbívoros associados a Copaifera lagsdorffii Desf. (Fabaceae: Caesalpinioideae) em área de transição Cerrado-Caatinga no Brasil. Ecología Austral 19: 197-206.

Silveira AP, Martins FR, Araújo FS. 2013. Do vegetative and reproductive phenophases of deciduous tropical species respond similarly to rainfall pulses? Journal of Forest Research 24: 643-651.

Singh KP, Kushwaha CP. 2005. Emerging paradigms of tree phenology in dry tropics. Current Science 89: 6-25.

Sloan SA, Zimmerman JK, Sabat AM. 2007. Phenology of Plumeria alba and its herbivores in a tropical dry forest. Biotropica 39: 195-201.

Souza ML, Fagundes M. 2014. Seed germination of Copaifera langsdorffii (Fabaceae): the role of seed size. American Journal Plant Sciences 5: 2566-2573.

Souza MLS, Fagundes M. 2016. Seed predation of Copaifera langsdorffii (Fabaceae): a tropical tree with supra-annual fruiting. Plant Species Biology. doi: 10.1111/1442-1984.12128.

Stamp N. 2003. Out of the quagmire of plant defense hypotheses. Quaterly Review of Biology 78: 23-55.

Swain T, Hillis WE. 1959. The phenolic constituents of Prunus domestica. I. - The quantitative analysis of phenolic constituents. Journal of the Science of Food and Agriculture 10: 63-68.

Thompson K, Gilbert F. 2014. Phenological synchrony between a plant and a specialized herbivore. Basic and Applied Ecology 15: 353-361.

Weiner J, Campbell LG, Pino J, Echarte L. 2009. The allometry of reproduction within plant populations. Journal of Ecology 97: 12201233.

Yang LH, Rudolf VHW. 2010. Phenology, ontogeny and the effects of climate change on the timing of species interactions. Ecology Letters 13: 1-10.

Yukawa J, Akimoto K. 2006. Influence of synchronization between adult emergence and host plant phenology on the population density of Pseudasphondylia neolitseae (Diptera: Cecidomyiidae) inducing leaf galls on Neolitsea sericea (Lauraceae). Population Ecology 48: 13-21. 